\title{
pN2 非小細胞肺癌の術後放射線照射による局所制御と予後
}

Postoperative Irradiation for pN2 Non-small Cell Lung Cancer

清水わか子 ${ }^{1)} \cdot$ 奥村敏之 $^{2)} \cdot$ 鬼塚正孝 $^{3)} \cdot$ 石川成美 $^{3)} \cdot$ 山本達生 ${ }^{3)}$

要旨：非小細胞肺癌 pN2 症例における術後放射線照射の意義を retrospective に解析する. (対象と方法) 1993 年 1 月より 1998 年 10 月までに術後照射が行われた病理学的 N2であった非小細胞肺癌 31 例を対象とした。男 女比は $23: 8$, 平均年齢 60.6 歳, 腺癌 18 , 大細胞癌 5 , 扁平上皮癌 8 であった.照射は術後平均 30.1 日で開始さ れた. $6 \mathrm{MV}$ または $10 \mathrm{MV}$-リニアック X 線で切除断端・縦隔・両鎖骨上窩を含む T 字照射野で 46〜 50Gy/23 〜28 回/5〜6 週, 断端陽性または近接例では 10〜 14Gy/5〜 7 回/1〜2 週を追加し総線量を $60 \mathrm{~Gy}$ とした. 平 均経過観察期間は 39.1 カ月であった. (結果) 3 年累積全生存率 (OAS) 65.6\%, 3 年無病生存率 (DFS) 40.7 $\% ， 3$ 年局所制御率（LC） $77.3 \%$ であった. 非扁平上皮癌では 20 例 $(87.0 \%)$ が $\mathrm{T} 1-2$ であったが, 扁平上 皮癌は 4 例 $(50.0 \%)$ がのみであった。また OAS，DFS，LC は扁平上皮癌で $87.5 \%, 100 \%, 100 \%$, 非扁平 上皮癌で $61.8 \%, 35.1 \%, 70.5 \%$ であり，DFS で有意差が認められた. (結論) 扁平上皮癌では術後照射によ る局所制御が予後を改善すると考えられるが, 非扁平上皮癌では, 遠隔転移が予後因子であり, 術後照射の 有用性は認められなかった。

〔肺癌 41 (1) : 33〜37, 2001, JJLC $41: 33 \sim 37,2001$ 〕

Key words : Non-small cell lung cancer, pN2, Postoperative irradiation, Non-squamous cell carcinoma, Distant metastasis

\section{1.はじめに}

非小細胞肺癌の根治的切除術後の予後は原発巣の進展 状況とリンパ節転移の有無によって左右される．特に術 後病理学的 N2 (以下 $\mathrm{pN} 2$ ) 例については予後不良であり, その治療方針についてさまざまな検討がなされてきた. Naruke ら ${ }^{1}$ は, 自験例にもとついて pN2 症例の予後解析 を行った. その結果, $\mathrm{pN} 2$ 手術症例 426 例中根治的切除 が可能であったのは 242 例 $(56.8 \%)$ であり，その 5 年生 存率は $19.2 \%$ と予後不良であった. そこで局所制御率お よび生存率の改善を目的に, 術後補助療法として放射線 治療や化学療法が行われてきた。1986 年にLung Cancer Study Group (LCSG) は II・III 期扁平上皮癌において縦隔 リンパ節・患側気管支断端を含む $50 \mathrm{~Gy}$ の術後照射によ る局所制御率の改善について報告した . それによると 症例全体では明らかな局所制御の改善は認められなかっ たが，pN2 症例で照射による改善傾向が認められた。こ の成績は，すでに行われてきた術後照射及び照射範囲を

\footnotetext{
1)癌研究会付属病院放射線治療科

2)茨城県立中央病院放射線科

3) 筑波大学臨床医学系

別刷請求先：清水わか子 君津中央病院（2001 年 4 月 1 日上り）

于292-8535 木更津市桜井 1010

TEL : 0438-36-1071

E-mail : BYA13222@nifty.ne.jp
}

理論的に支持するものであった.

われわれは, 現在 $\mathrm{pN} 2$ 症例に対して両鎖骨上窩・縦隔 リンパ節・患側気管支断端を含む 50Gy/25２8 回の術 後照射を行っている. 今回 $\mathrm{pN} 2$ で術後照射を施行した症 例の予後と再発形式を retrospective に解析し, 問題点と 術後照射の意義について検討した。

\section{2. 対象と方法}

1993 年 1 月より 1998 年 10 月までに非小細胞肺癌で 根治的手術後に放射線照射が行われたのは 47 例であっ た.このうち pN2 であった 31 例を対象とした(Table 1).

放射線治療は， $6 \mathrm{MV}$ または $10 \mathrm{MV}$-リニアック X 線を 用い, 総線量は 46〜 50Gy/23〜28 回/5〜6 週とした。照 射野は基本的に切除断端, 縦隔, 再鎖骨上窩を含む $\mathrm{T}$ 字型を基本とした。さらに, 病理組織学的に切除断端が 陽性であったり，肉眼的に近接していた場合には切除断 端に 10〜 14Gy/5〜 7 回/1〜2 週を追加照射し, 総線量を 60Gy とした. 局所への追加照射では脊髄を外し, 脊髄線 量は $50 \mathrm{~Gy} / 25 \mathrm{Fr}$ を超えないこととした. 原則として化学 療法の追加・併用は行わなかった。しかし, リンパ節転 移数の多かった症例など 4 例で化学療法の追加または同 時併用が行われたが, 症例数が少ないため, 化学療法の 効果については検討しなかった。

累積生存率・局所制御率は手術日を起点として Kaplan-Meier 法により算出し，有意差の検定には Log-rank 
Table 1. Patient Characteristics

\begin{tabular}{|c|c|c|}
\hline Gender & $\mathrm{M}: \mathrm{F}$ & $23: 8$ \\
\hline \multicolumn{2}{|c|}{ Mean age (years) $\langle$ range $\rangle$} & $60.6(33-77)$ \\
\hline \multicolumn{2}{|c|}{ Mean follow-up (months) $\langle$ range $\rangle$} & $39.1(7-72)$ \\
\hline \multirow[t]{3}{*}{ Pathological diagnosis } & adeno ca. & 18 \\
\hline & large cell ca. & 5 \\
\hline & squamous ca. & 8 \\
\hline \multirow[t]{4}{*}{ Pathological T stage } & $\mathrm{T} 1$ & 11 \\
\hline & $\mathrm{T} 2$ & 13 \\
\hline & $\mathrm{T} 3$ & 4 \\
\hline & $\mathrm{T} 4$ & 3 \\
\hline \multirow[t]{3}{*}{ Operation } & lobectomy & 26 \\
\hline & bilobectomy & 2 \\
\hline & pneumonectomy & 2 \\
\hline \multicolumn{3}{|c|}{ Interval between operation and radiation (days) $\langle$ range $\rangle$} \\
\hline \multicolumn{2}{|c|}{ Combined with chemotherapy } & 4 \\
\hline
\end{tabular}

Fig. 1. Overall survival and disease free survival

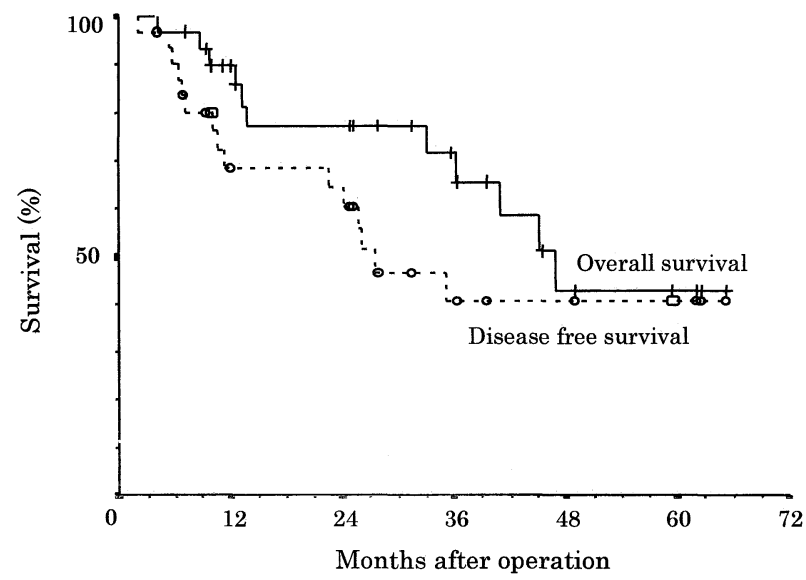

test, $\chi^{2}$ test を用いた.

\section{3. 結 果}

全症例の 3 年累積全生存率 (overall survival rate, 以下 $\mathrm{OAS}), 3$ 年無病生存率 (disease-free survival rate, 以下 DFS), 3 年局所制御率 (local control rate, 以下 LC) は, 65.6\%，40.7\%，77.3\%であった (Fig. 1). 切除断端陽性 5 例のうち 4 例に総線量 $60 \mathrm{~Gy}$ までの追加照射が行われ た. 組織型と切除断端陽性率に相関はなく(Table. 3), ま た切除断端陽性の有無と OASには有意差は認められな かった (Fig. 2). LC についても全く同様の傾向がみられ た。

切除標本における原発巣の pT-stage と OAS の関連を 検討した. pT3-4 症例 7 例は pT1-2 よりも良好な生存率 を示した (Fig. 3). Table. 2 に示した通り, pN2 症例の中 でも腺癌を主とする非扁平上皮癌の多くは原発巣が小さ く周囲組織への浸潤を認めない pT1-2 が多かったが, 扁
Fig. 2. Overall survival according to negative or positive surgical margin

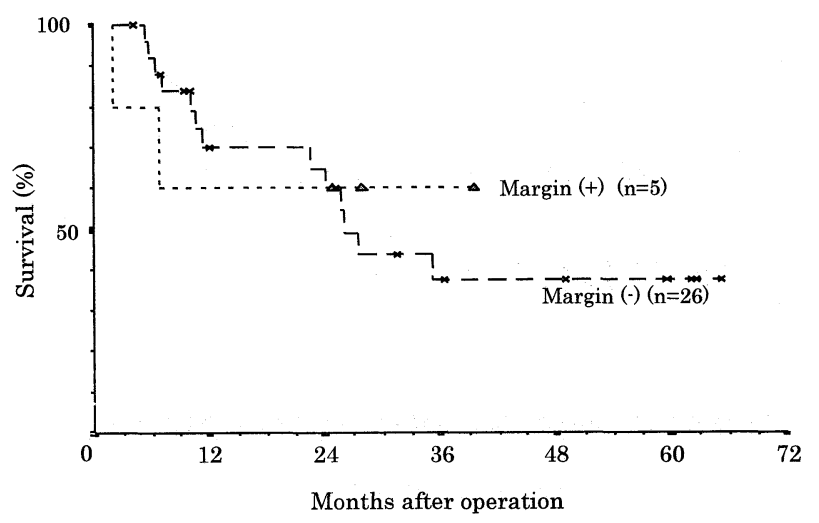

Fig. 3. Overall survival according to pathological $\mathrm{T}$ stage

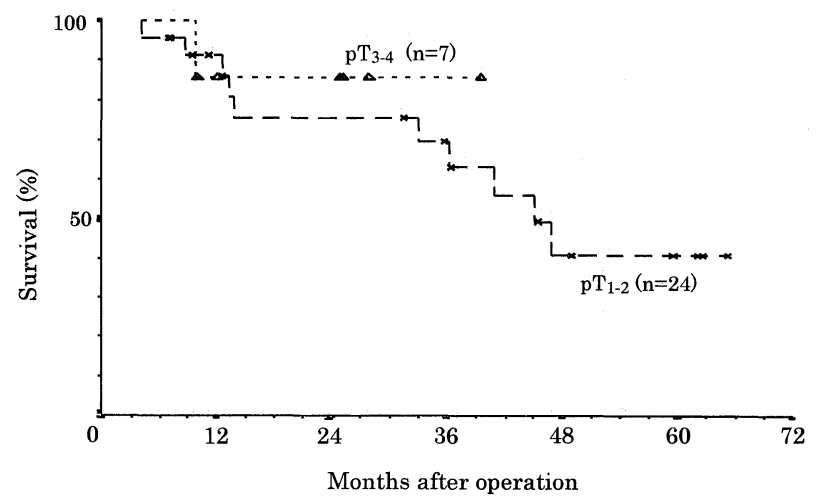

Table 2. Histological type and p T-stage

\begin{tabular}{l|c|c}
\hline & pT1-2 & pT3-4 \\
\hline Squamous & 4 & 4 \\
Non-squamous & 20 & 3 \\
\hline
\end{tabular}

Table 3. Histological type and surgical margin

\begin{tabular}{l|c|c}
\hline & Margin negative & Margin positive \\
\hline Squamous & 7 & 1 \\
Non-squamous & 19 & 4 \\
\hline
\end{tabular}

平上皮癌では特にpT-stage の偏りを認めなかった.この 結果から組織型が予後に影響していると考えられ, 扁平 上皮癌と非扁平上皮癌に分けて予後を比較した。OAS， DFS, LC は, 扁平上皮癌では $87.5 \%, 100 \%, 100 \%$ であっ たが, 非扁平上皮癌はそれぞれ $61.8 \%, 35.1 \%, 70.5 \%$ で あった．組織型により LCには明らかな違いを認めな かったが (Fig. 4)，非扁平上皮癌では OAS・DFS が扁平 上皮癌に比べて有意に不良であった（Fig. 5). 
Fig. 4. Local control : squamous cell carcinoma (Sq) vs. nonsquamous cell carcinoma (Non-sq)

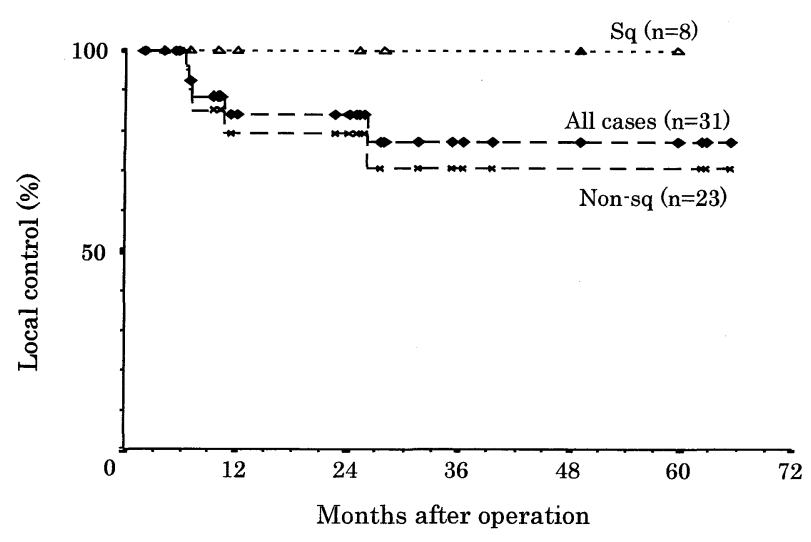

Fig. 5. Overall survival and disease free survival : squamous cell carcinoma vs. non-squamous cell carcinoma

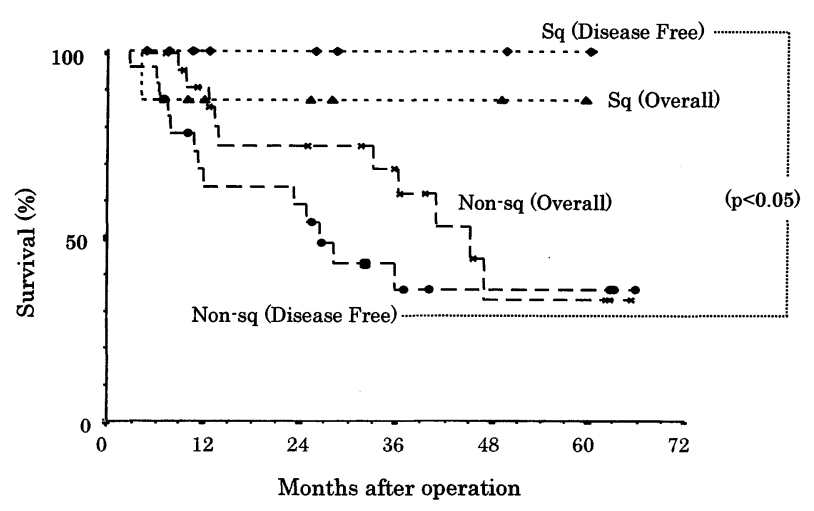

\section{4. 考 察}

放射線治療は局所治療であり，術後照射は局所制御に よって予後を改善しようとするものである，扁平上皮癌 のみを対象とした LCSG の報告 ${ }^{2}$ では $\mathrm{pN} 2$ 症例での局所 制御率に改善傾向が認められた。また，松毛ら ${ }^{3)}$ は pN2 肺癌手術後の長期生存者には扁平上皮癌が多いこと, 病 理学的に断端陽性であっても長期生存している症例があ り, その症例に対しては術後照射が施行されていること を報告した。この 2 つの報告からは，扁平上皮癌には術 後照射が局所制御という点で有用であると考えられる. 照射線量については, Debevac ら")の報告では $30 \mathrm{~Gy} / 10$ 回 $/ 2$ 週では予後の改善が認められず, LCSG の 50Gy/25 〜28 回/5〜6 週で局所制御率の改善傾向が認められる ことから, 50Gy あるいはそれ以上の線量が望ましいと考 えられる.われわれの症例では線量的には LCSG と同等 であるが, 現在まで切除範囲内の局所再発は 1 例のみで あり，照射線量は妥当であると判断される.

一方, 高橋ら ${ }^{6)}$ は術後 $\mathrm{pN} 2$ 腺癌においては原発巣が $\mathrm{T}$ $1 / \mathrm{T} 2$ が圧倒的に多いというわれわれのデータと同様の
傾向を報告し, さらに腺癌の場合, 術前診断でリンパ節 転移を十分に評価できないこと㧍よび再発形式としては 遠隔転移が多いことを報告している。転移リンパ節個数 と予後の関連を報告した中田ら゙によれば, 腺癌において は転移個数が増えるにしたがい明らかに予後が不良と なった。八柳ら ${ }^{8}$ は, 中田らと同様，リンパ節転移 5 個以 上の場合に予後が不良であったと報告した．今後は病理 所見で転移リンパ節の個数や部位について更に詳細な データを蓄積する必要がある.

今回の検討で, $\mathrm{pN} 2$ 扁平上皮癌は治癒切除と 50Gy の 術後照射で局所制御がえられ，良好な予後が期待できる ことが示された。一方, 非扁平上皮癌は, 扁平上皮癌と は全く異なり，原発巣が $\mathrm{T} 1 / \mathrm{T} 2$ であってもリンパ節転移 が多いこと，および局所制御の向上が予後の改善に寄与 しないことが明らかになった．非扁平上皮癌の予後改善 には今後, 放射線治療のような術後局所治療上りも遠隔 転移を十分に抑制できる有効な治療法の開発が不可欠で あり，その上で手術・放射線治療などの局所治療との組 み合わせた治療戦略を確立する必要性がある。

Arriagata9 によると, 非小細胞肺癌に対しては術前照射 または術後照射が広く行われているにもかかわらずその 有用性については明らかになっていない．現時点では術 前に放射線化学療法あるいは化学療法で腫瘍を縮小させ resectability の向上を期待するいわゆる induction therapy が一つの主流になっている.

術前化学療法については Roth ら ${ }^{10}$ は, IIIA 期非小細胞 肺癌を対象とした無作為抽出試験を施行し, 術前・術後 の化学療法による生存率の改善はみられたが, 術前化学 療法に上る切除率の向上は少なく, 不完全切除または切 除不能と判断された症例が $50 \%$ 以上と報告した。また， Rosell ら ${ }^{11}$ は, 術前化学療法と 40Gy の術後照射の併用に よる全生存率㧍よび無病生存率の改善を報告している が, 化学療法の奏効率は $60 \%$ と低く, 局所制御率の改善 は認められていない.

一方, 術前放射線化学療法の代表的なものとしては, 1995 年に Southwest Oncology Group（SWOG）の 第 II 相試験 8805 が報告された ${ }^{22}$ 。これによると, 手術時に縦 隔リンパ節の消失が病理学的に証明された症例の予後が 有意に良好であった。この SWOG の対象症例中手術不能 例に対しては可及的に60Gy までの追加照射が行われ た ${ }^{13)}$ が，その予後は手術可能であった症例と差が無かっ た.このことは放射線化学療法が有効である症例に対す る外科治療の必要性について一つの問題を提起した.

いずれの報告においても, 組織型別の分析は行われて いない.しかし, Movsasらら ${ }^{14} に$ にれば, RTOGの clinical trial で扁平上皮癌と非扁平上皮癌では治療効果・予後に 有意差が認められた。扁平上皮癌においては, 今後, 術 前治療と外科切除のそれぞれの対象をどうするか，また 
術後照射とどのように組み合わせるかについての臨床試 験などが望まれる，同時に局所制御が予後と相関する扁 平上皮癌においては化学療法の役割についても再検討が 必要と思われる.

一方，非扁平上皮癌においては，予後の改善には遠隔 転移の制御を目的とした治療法の改善が待たれ，外科切 除や術後照射などの局所制御を目的とした治療法とどの ように組み合わせるかを検討する必要がある，T1NO 症 例でも扁平上皮癌に比べて非扁平上皮癌の遠隔転移が多 く予後が不良である ${ }^{15)}$ こを考慮すると, induction therapy が比較的早期の非扁平上皮癌症例の予後を改善する 可能性も期待される.

\section{5. まとめ}

1） $50 \mathrm{~Gy} / 25$ 回/5 週の縦隔への術後照射と断端陽性部 分に対する $10 \mathrm{~Gy} / 5$ 回/1 週の追加照射は非小細胞肺癌の 局所制御に寄与しているものと考えられる.

2）扁平上皮癌については局所制御により，無病生存 する可能性が高い.

3）非扁平上皮癌では，扁平上皮癌と局所制御率には 差がみられないが, 遠隔転移の発生率が有意に高く, 予 後不良であった，今後，遠隔転移の制御するような治療 の開発と局所治療との適切な組み合わせが予後の改善に 不可欠である.

\section{文}

1) Naruke $T$, Goya $T$, Tsuchiya $R$, et al : The importance of surgery to non-small cell carcinoma of the lung with mediastinal lymph node metastasis. Ann Thorac Surg 46 : 603610, 1988.

2) The Lung Cancer Study Group : Effects of postoperative mediastinal radiation on completely resected stage II and stage III epidermoid cancer of the lung. N Eng J Med 315 : 1377-1381, 1986.

3）松毛真一, 細川誉至雄, 村上洋平, 他：P-N2 非小細胞肺 癌長期生存症例の検討. 胸部外科 $52: 911-914,1999$.

4) Debevac M, Bitec M, Vidmir S, et al : Postoperative radiotherapy for radically resected N2 non-small-cell lung cancer (NSCLC) : randomised clinical study 1998-1992. Lung Cancer $14:$ 99-107, 1996.

5）大原潔，奥村敏之，立崎英夫，他：肺癌術後照射の意義. 肺癌 $29: 9-18,1989$

6）高橋 渉, 奥脇英人, 吉井新平, 他：自験例からみた $\mathrm{pN}$ 2 肺癌手術成績向上に向けての考察. 胸部外科 $52: 906$ 910, 1999.

7）中田昌男, 佐伯英行, 栗田 啓, 他：非小細胞肺癌切除例 における転移リンパ節個数による予後解析の試み. 肺癌 39 : 421-427, 1999.

8）八柳英治, 平田 哲, 森山博史, 他：p-N2 非小細胞肺癌 の縦隔りンパ節転移様式と予後因子の検討。日呼外会誌 $12: 2-9,1998$.

9) Arriagata $\mathrm{R}$ : Current strategies for radiation therapy in non-small cell lung cancer. Chest 112 (4 Suppl) : 209S-
213S, 1997

10) Roth JA, Fossella F, Komaki R, et al : A randomised trial comparing perioperative chemotherapy and surgery alone in resectable stage IIIA non-small-cell lung cancer. J Natl Cancer Inst 86 : 673-680, 1994.

11) Rosell R, Gomez-Codina J, Camps C, et al : A randomised trial comparing preoperative chemotherapy plus surgery with surgery alone in patients with non-small-cell lung cancer. N Eng J Med 330 : 153-158, 1994.

12) Albain KS, Rusch VW, Crowley JJ, et al : Concurrent cisplatin/etoposide plus chest radiotherapy followed by surgery for stages IIIA (N2) and IIIB non-small-cell lung cancer : mature results of Southwest Oncology Group phase II study 8805. J Clin Oncol 13 : 1880-1892, 1995.

13) Lau DH, Crowley JJ, Gandara DR, et al : Southwest Oncology Group phase II trial of concurrent carboplatin, etoposide, and radiation for poor-risk stage III non-smallcell lung cancer. J Clin Oncol 16 : 3078-3081, 1998.

14) Movsas B, Scott C, Sause W, et al : The benefit of treatment intensification is age and histology-dependent in patients with locally advanced non-small cell lung cancer (NSCLC) : a quality-adjusted survival analysis of radiation therapy oncology group (RTOG) chemoradiation studies. Int J Radiat Oncol Biol Phys 45 : 1143-9, 1999.

15) Deslauriers J, Gregoire $J$ : Surgical therapy for early nonsmall cell lung cancer. Chest 117 (4 Suppl 1) : 104S-109S, 2000 . 


\title{
Postoperative Irradiation for pN2 Non-small Cell Lung Cancer
}

\author{
Wakako Shimizu ${ }^{1)}$, Toshiyuki Okumura ${ }^{2)}$, Masataka Onitsuka ${ }^{3)}$, \\ Shigemi Ishikawa ${ }^{\text {s) }}$ and Tatsuo Yamamoto ${ }^{3)}$ \\ 1) Division of Radiation Oncology, Cancer Institase Hospital \\ 2) Department of Radiology, Ibaraki Prefectural Central Hospital \\ 3) College of Clinical Medicine, University of Tsukuba
}

Objective : The efficacy of postoperative irradiation for pN2 non-small lung cancer was evaluated retrospectively.

Methods : Between January 1993 and October 1998, 31 patients with pathologically proven N2 non-small cell lung cancer underwent postoperative radiotherapy. There were 23 men and 8 wemen (mean age 60.6 years). The histologie was squamous cell carcinoma in 8 patients and non-squamous cell carcinoma in 23 . The mean interval between operation and irradiation was 30.1 days. The irradiated fields included the surgical margin, mediastinal and bilateral supraclavicular lymph nodes. In cases with negative surgical margins, the total dose was 46-50Gy, administered in 23-28 fractions over 5-6 weeks. A boost irradiation was added to positive surgical margins with a dose of 10-14Gy in 2 weeks. The mean follow-up period was 39.1 months.

Results : Three-year overall survival rate was $65.6 \%$, three-year disease-free survival rate $40.7 \%$, and three-year local control rate $77.3 \%$. Twenty patients $(87.0 \%$ ) with non-squamous cell carcinoma had small primary lesions T1-2, while four patients $(50.0 \%)$ with squamous cell carcinoma had advanced primary lesions T3-4. The three-year disease-free survival rate for squamous cell carcinoma was $100 \%$, while that for non-squamous cell carcinoma was significantly lower at $35.1 \%$.

Conclusion : Postoperative irradiation may be effective for squamous cell carcinoma of the lung with pathological N2 status by improving local control. In adenocarcinoma, the benefit of postoperative irradiation is controversial.

[JJLC $41: 33 \sim 37,2001]$ 